\title{
イソチオシアナート化合物の抗菌活性
}

\author{
岸本憲明*・田野達男*・原田靖裕**・増田秀樹**
}

\section{Antimicrobial Activities of Isothiocyanate Compounds}

\author{
KISHIMOTO Noriaki*, TANO Tatsuo*, HaRAdA Yasuhiro** \\ and MASUdA Hideki** \\ * Department of Food and Lifestyle, Faculty of Food Culture, Kurashiki Sakuyo University, \\ 3515 Nagao Tamashima, Kurashiki-city, Okayama 710-0251 \\ * Material $R$ \& $D$ Laboratories, Ogawa \& Co., Ltd., \\ 1-2, Taiheidai, Shoo-cho, Katsuta-gun, Okayama 709-4321
}

The nineteen isothiocyanate compounds with five kinds of functional groups, alkyl, $\omega^{-}$ alkenyl, aryl, $\omega^{-m e t h y l t h i o a l k y l, ~ a n d ~} \omega$-methylsulfinylalkyl, were tested for minimum inhibitory concentration against growth of four species of bacteria and two species of fungi. In general, the isothiocyanate (ITC) analogues showed antimicrobial activities according to the following order: aryl ITC $>\omega$-methylthioalkyl ITC $>\omega$-alkenyl ITC $>\omega$-methylsulfinylalkyl ITC $>$ alkyl ITC. They also had different antimicrobial spectra. The aryl and $\omega^{-}$ mithylthioalkyl ITCs indicated higher antimicrobial activity against gram-positive becteria and fungi than gram-negative bacteria, whereas w-alkenyl ITCs were more effective against gram -negative bacteria and fungi than gram-positive bacteria. Gram-positive bacteria and $A$. niger were more sensitive to the $\omega$-methylsulfinylalkyl ITCs than gram-negative bacteria and $C$. albicans. The antimicrobial activity was increased by a combination of ITCs having different antimicrobial spectra. The ITCs other than alkyl ITC inhibited the growth of methicillin resistant Staphylococcus aureus and methicillin sensitive $S$. aureus at the same concentration. The antimicrobial activity of ITC analogues other than alkyl ITC is about 5 to 10 times those of preservatives generally used in foods.

(Received Sep. 28, 1998)

食の外食化や調理済み、半調理済み食品の消費が急増 する一方で, 消費者の健康と安全に対する関心が高まっ てきている。水分活性值の高い調理済み食品をチルド流 通や常温流通経路にのせるためには, 食品産業における 微生物制御がますます重要な課題となっている。無菌包 装や無菌化工場で生産された食品はいまだ少なく，有用
な殺菌剂や保存料の開発が求められているなかで, 食経
験のある食用植物の成分を食品の保存に利用する試みが
進められている
ワサビやカラシ
ら知られている。ア精油に抗菌作用があることは古くか
は精油の主要な成分で, 揮発しやすく刺激的な辛味を呈

*くらしき作陽大学食文化学部（テ710-0251 岡山県倉敷市玉島長尾3515）

**小川香料株式会社素材研究所（干709-4321 岡山県勝田郡勝央太平台1-2） 
するとともに抗菌力をもつことが報告されている4 サビ抽出物や AIT は培地への添加よりも, 蒸気接触さ せた方が抗菌スペクトルも広く, 生育阻止濃度も低くな ることが明らかにされ ${ }^{5)}$-8), 食品表面での微生物增殖 抑制に応用されている。

AIT 以外に, 量は少ないものの, 種々の側鎖構造を もつイソチオシアナート（ITC）類が食用植物や果実か ら単離同定されている。伊奈ら ${ }^{9), 10)}$ は，沢ワサビの特徵 的な香気成分として MeS-NCS) 類と $\omega^{-M e t h y l s u l f i n y l a l k y l ~ I T C ~(~} \omega^{-}$ $\mathrm{MeSO}-\mathrm{NCS}$ ) 類を単離, $\mathrm{TANG}^{11)}$ はパパイアから Benzyl ITC を検出し, ホースラディッシュからは Phenethyl ITC が, クレソンからは7-Methylthioheptyl ITC (7-Mes-NCS) が同定されている12)。 また, MASUDA ら ${ }^{13)}$ は沢ワサビとホースラディッシュ から，側鎖構造の異なる 4 種類14の ITC 類を報告して いる。

AIT の抗菌作用は詳細に研究されている(6) 8) が, AIT 以外の ITC 類については断片的な抗菌活性か報告 されているだけで，ITC の側鎖構造と抗菌活性を系統 的に研究した報告はまだ見あたらない。

本研究では, 沢ワサビや，ホースラディッシュに存在 が報告されている 5 種類の側鎖をもつ19のITC類を調 製し，それらの抗菌活性を測定して，側鎖構造と抗菌活 性の関係を系統的に調べた。

\section{実験材料および方法}

\section{1. 試料}

Isopropyol ITC は May Bridge Co. Ltd. (UK) から, Isopropyl ITC 以外の Alkyl ITC 類と Aryl ITC 類, AIT は東京化成工業㑣から購入した。AIT 以 外の $\omega$-Alkenyl ITC 類はアルケニルハライドをチオ シアン塩酸と反応させ， $\omega-\mathrm{MeS}-\mathrm{NCS} と \omega-\mathrm{MeSO}-$ NCS 類は $\omega$-Alkenyl ITC とアルキルメルカプタンか ら有機合成した ${ }^{14)}$,15)。食味保存料はナカライテスク侏 から購入した。

\section{2. 微生物と培地}

次の供試株を検定菌として用いた。グラム陽性菌とし てBacillus subtilis IFO $3134 と$ methicillin sensitive Staphylococcus aureus IFO 12732 ( MSSA), methicillin resistant $S$. aureus (MRSA), グラム陰 性菌としてEscherichia coli IFO 3301とPseudomonas aeruginosa IFO 3080, 真菌として Candida albicans IFO 1385とAspergillus niger IFO 4414を使用した。 MRSA は広島県環境保健協会・村上和保博士から分譲
された菌株で，オキサシリン KB disk で生育阻止域を 全く形成しない薬剤耐性株である。

細菌の培養には，ぺプトン $5.0 \mathrm{~g} ，$ 酵母エキス $1.5 \mathrm{~g}$ ， 肉エキス $1.5 \mathrm{~g}, \mathrm{NaCl} 3.5 \mathrm{~g}$, グルコース $1.0 \mathrm{~g}, \mathrm{Na}_{2}$ $\mathrm{HPO}_{4} 3.0 \mathrm{~g}, \mathrm{KH}_{2} \mathrm{PO}_{4} 1.32 \mathrm{~g}$ (蒸留水1,000m㧒溶解, $\mathrm{pH} 7.0$ 7.1）培地 ${ }^{16)}$ を, 真菌の培養にはサブロ一培地 (ペプトン $10.0 \mathrm{~g}$, グルコース $40.0 \mathrm{~g}$, 蒸留水 $1,000 \mathrm{~m} \ell$ に溶解，pH5.5〜6.0に調整）を使用した。

\section{3. 抗菌活性の測定方法}

試料は $80 \%$ メタノール溶液に $10,000 \mathrm{ppm}$ となるよう に溶解した。B. subtilisと A. nigerは胞子懸濁液を調製 し, $1 \times 10^{4} \sim 10^{5}$ cells $/ \mathrm{m} \ell$ なるように, 残りの微生 物は前培養した栄養細胞を $1 \times 10^{4} \sim 10^{5}$ cells $/ \mathrm{m} \ell$ と るように培地に接種後，96穴マイクロプレートの第 1

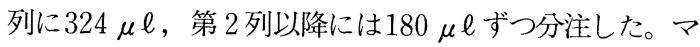
イクロプレートの第 1 列に試料溶液 $36 \mu l$ (終濃度1, $000 \mathrm{ppm}$ ）添加した後，第 2 列以降一連続 2 倍希釈した。 細菌は $35^{\circ} \mathrm{C}$ で 6 時間静置培養後, 培養液の濁度 $(630$ $\mathrm{nm}$ ）をマイクロプレートリーダーで測定した。真菌は $25^{\circ} \mathrm{C}$ で22時間培養後，C. albicans は培養液の濁度と菌 糸形への変化を顕微鏡で, A. niger は胞子の発芽を顕 微鏡で観察した。濁度が 0.05 以下の培養液は透明で, 菌の生育が認められなかったため，0.05以下の数值を 示した希橎列の試料濃度を生育阻止最小濃度 (MIC) とした。実験は 3 回おこない, 平均値を求めた。

試料を添加しない $80 \%$ メタノール溶液希釈列をコン トロールとした。コントロールの列にはいずれの微生物 も生育することを確認した。

\section{結果}

\section{1.グラム陽性細菌に対する抗菌活性}

Alkyl ITC 類はいずれも抗菌力が弱く, 反対に Aryl, $\omega-\mathrm{MeS}-\mathrm{NCS}, \omega-\mathrm{MeSO}-\mathrm{NCS}$ 類は, $100 \mathrm{ppm}$ 以下で細菌の生育を阻止し, 強い抗菌力を示した

(Fig. 1)。とくに Benzyl ITCと2-Phenethyl ITC, 3-MeS-NCS, 5-MeS-NCS, 6-MeS-NCS は, ワサ ビに最も多く含まれている AIT の 5 〜 10倍強い抗菌活 性を示した。Alkyl ITC 以外の ITC 類は, MRSAに 対しても MSSA と同程度の抗菌力を示した。

\section{2.グラム陰性細菌に対する抗菌活性}

๗-Alkenyl ITC 類と Benzyl ITC, 3-MeS-NCS は グラム陰性菌に高い抗菌活性を示した（Fig. 2)。ゅAlkenyl ITC と $\omega$-MeS-NCS 類の多くは, E. coliよ $\eta P$. aeruginosa の生育を強く阻止し, 反対に Aryl ITC と ${ }^{-M e S O-N C S}$ 類は, $P$. aeruginosaより $E$. 


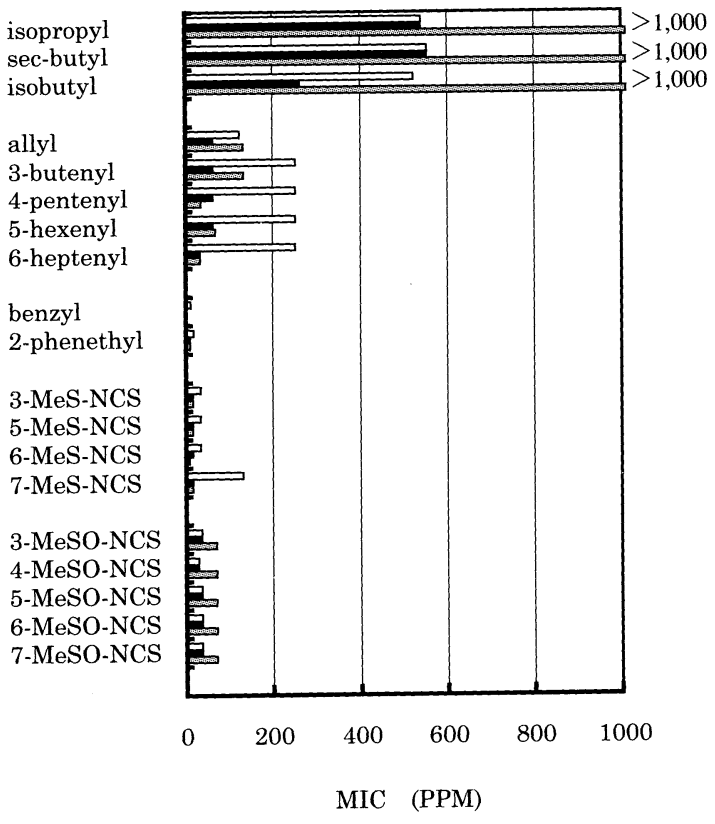

Fig. 1 Antimicrobial activity of ITCs against grampositive bacteria.

Antimicrobial activity was assayed using a 96 holes microplate by the continuous 2 fold dilution method. After incubation at $35^{\circ} \mathrm{C}$ for $6 \mathrm{~h}$ (bacteria) and at $25^{\circ} \mathrm{C}$ for $22 \mathrm{~h}$ (fungi), their turbidity were measured by a microplate reader at $630 \mathrm{~nm}$. Growth inhibition against $A$. niger and $C$. albicans was determined on the result of germination of spores or cells observed under a microscope. Minimum inhibitory concentration (MIC) was defined as the concentration of the sample which complely inhibited the growth of microorganism.

Symbols: $\square$ B. subtilis. $\square$ MSSA $M$ MRSA

coli の生育をよく阻害した。Aryl ITC と NCS，๘-MeSO-NCS 類では，側鎖の炭素鎖が短いほ ど一般に抗菌活性が高くなった。

\section{3. 真菌に対する抗菌活性}

$\omega$-Alkenyl ITCとAryl ITC, $\omega$-MeS-NCS 類は40 $\mathrm{ppm}$ 以下で $A$. niger と $C$. albicans の生育を阻止し た。一方，心-MeSO-NCS 類は，力ビと酵母で抗菌力 が異なり，A. niger の生育は60ppm 以下で阻止した が, C. albicans に対する抗菌力は弱く, 生育阻止に $500 \mathrm{ppm}$ 必要とする ITC もあった（Fig. 3 )。心ー MeSO-NCS 類では側鎖の炭素鎖が長くなるほど，C． albicans に対して強い抗菌力を示方傾向が認められた。

\section{4. 側鎖構造が異なる 3 種類の ITC 類の組み合わせが 抗菌活性に与える効果}

$\omega$-Alkenyl ITC 類と Aryl ITC, $\omega$-MeS-NCS 類 の中から, 抗菌活性の高い ITC を3つ(6-Heptenyl ITC, Benzyl ITC, 3-MeS-NCS) 選出L, 単独, 2

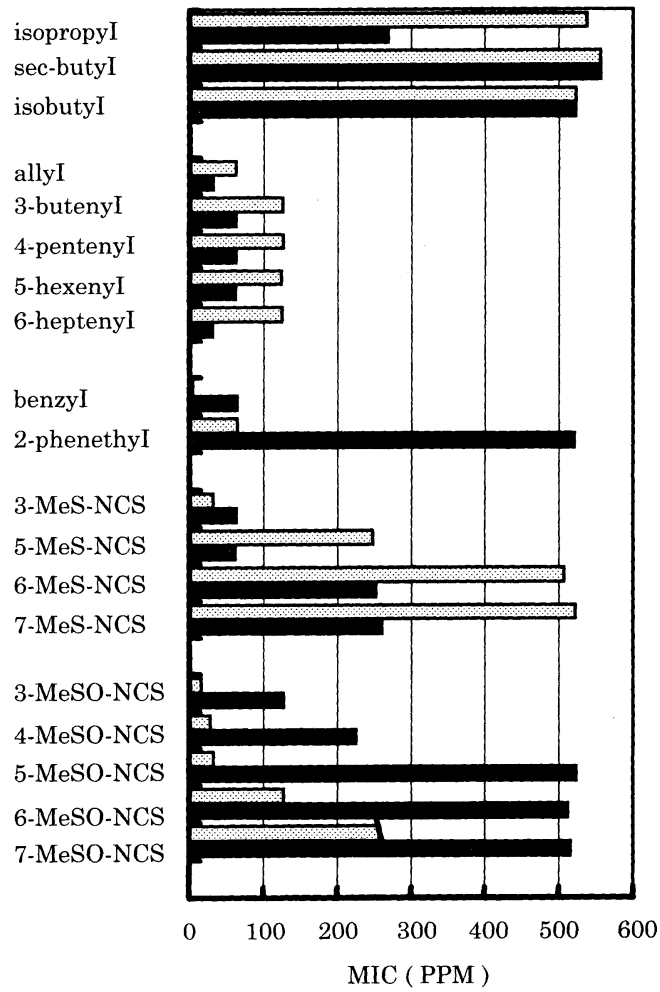

Fig. 2 Antimicrobial activity of ITCs against gramnegative bacteria.

The assay conditions are described in Fig. 1 . Symbols:

D. coli, $\longrightarrow$. aeruginosa

つあるいは 3 つ組み合わせたときの抗菌力を測定した

(Fig. 4)。試料は，いずれも終濃度 $10,000 \mathrm{ppm}$ とな るように調整した。

6-Heptenyl ITC は B. subtilis と E. coliに対する 抗菌力が弱いのに対して，3-MeS-NCS と Benzyl ITC は, $P$. aeruginosa に対方る抗菌力が弱いという特 徵をもっている。6-Heptenyl ITCに 3-MeS-NCS あ るいは Benzyl ITC を組み合わせると, 6-Heptenyl ITC単独より $B$. subtilis に対する抗菌力が 4 倍, $E$. coli に対する抗菌力が $2 \sim 9$ 倍増強された。一方，3MeS-NCS あるいは Benzyl ITC 単独添加に比べる と, P. aeruginosa に対する抗菌力は, 6-Heptenyl ITC が共存することにより2 倍上昇した。単独添加あ るいは 2 種類の ITC を組み合わせても50ppm で供試株 全ての生育を阻止できなかったが，3種類のITC を組 み合わせると, 生育阻止が可能となった。

\section{5 . 食品保存料とITC類の抗菌活性の比較}

ITC 類と同一条件で, 代表的な食品保存料 7 つの抗 


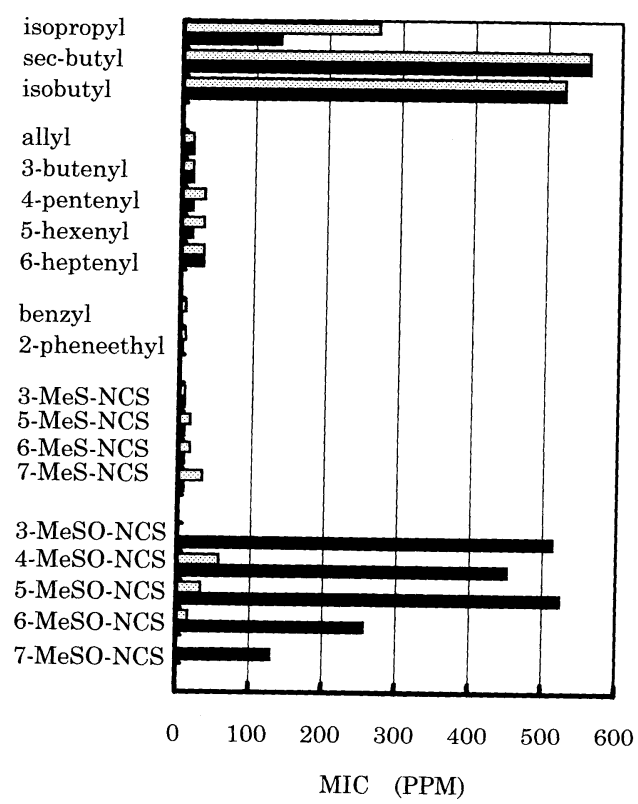

Fig. 3 Antimicrobial activity of ITCs against fungi. The assay conditions are described in Fig. 1. Symbols:

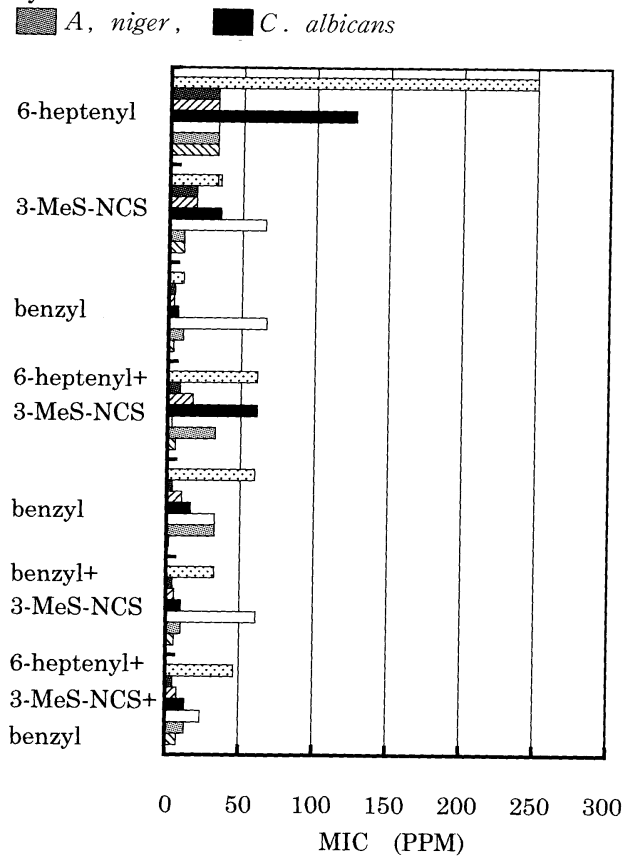

Fig. 4 Effect of combination of w-alkenyl ITC, aryl ITC, and $\omega-\mathrm{MeS}-\mathrm{NCS}$ on their antimicrobial activiy .

The assay conditions are described in Fig. 1. Symbols:
B $B$. subtilis,
MSSA, UIA MRSA,
E. coli,
$P$. aeruginosa, $A$. niger, $\mathbb{M}$. albicans.

菌活性を測定し MIC 值を比較した（Fig. 5 )。最も抗 菌力が強かったのは, p-Hydroxybenzoic acid butylester, ついで Propionic acid と $p$-Hydroxybenzoic acid propylester であった。真菌に抗菌活 性をもつデヒドロ酩酸Naは，C. albicans と A. niger の生育を30〜60ppm で阻害したが，細菌には抗菌活性 が認められなかった。安息香酸 $\mathrm{Na}$ とソルビン酸Kは 1,000ppm でも抗菌活性が認められなかった。Alkyl ITC を除いた ITC 類は, 今回検討した食品保存料に比 べて 5〜10倍高い抗菌活性を示した。

\section{考察}

今回検討した 7 株について，ITC の側鎖構造と抗菌 活性の間に密接な関係が認奴た。5 種類の側鎖をも つ ITC の中では Aryl ITC 類の抗菌力が強く, 反対に Alkyl ITC 類の抗菌力は弱かった。芳香族 ITC 類が 脂肪族 ITC 類より高い抗力ビ活性を示すことは

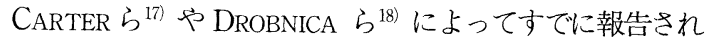
ている。今回，カビだけでなく細菌に対しても芳香族 ITC 類が脂肪族 ITC 類より高い抗菌活性を示すことを 明らかにすることができた。

ITC 類の側鎖構造が抗菌活性の高さに与える効果は,

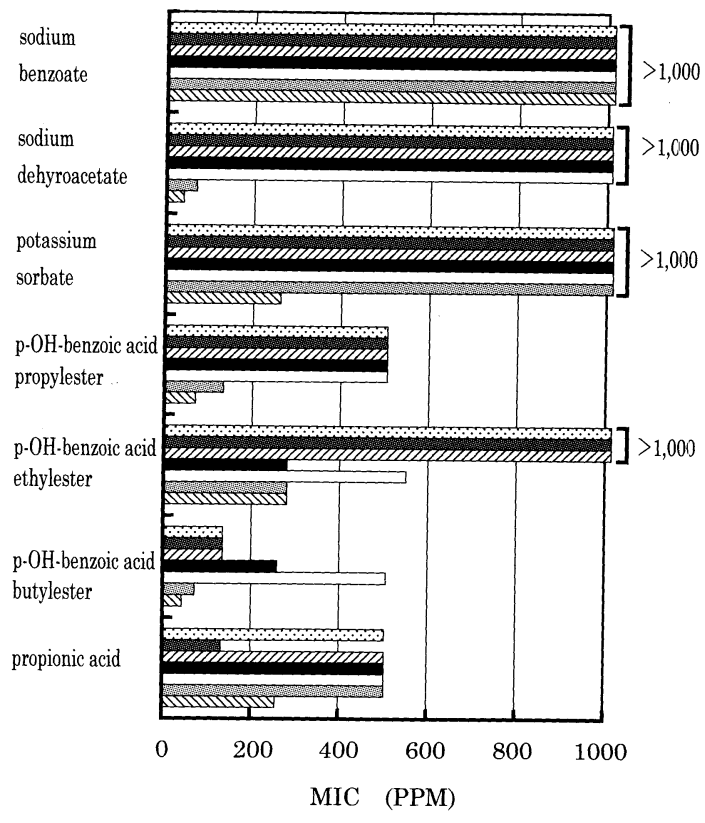

Fig. 5 Antimicrobial activity of food preservatives. The assay conditions are described in Fig. 1. Symbols:

B B. subtilis, MSSA, UMRSA, E. coli, $\square P$. aeruginosa, $\square A$. niger, $C$. albicans. 
イソチオシアネート基（- $\mathrm{N}=\mathrm{C}=\mathrm{S})$ の活性化と細胞表 層の構造（菌体表面構造あるいは細胞内への透過性）の 違いによると考えられる。イソチオシアネート基が ITC 類の抗菌活性の発現に重要であり，側鎖に二重結 合や芳香環，メチルチオ基，スルフィニル基が存在する と，イソチオシアネート基がより活性化され，抗菌力が 増大すると考えられる。しかも，イソチオシアネート基 と側鎖の二重結合やメチルチオ基，スルフィニル基との 距離が近いほど，言い換えると，側鎖の炭素鎖が短いほ どイソチオシアネート基が活性化され，抗菌力が増大す ると推測される。側鎖の炭素鎖が短いほど，グラム陰性 菌に対する抗菌活性が高かった今回の結果は，この推測 を支持している。しかし，グラム陽性，陰性細菌と真菌 ではそれぞれ細胞表層の構造や構成成分が異なるため, 側鎖構造の違いだけで，抗菌力の強さを説明することは 難しい。ITC 類の細胞内への透過性や菌体たんぱく質 との結合に側鎖構造が影響を与えている可能性も考慮す る必要がある。

ISSHIKI ら ${ }^{6)}$ は，グラム陰性菌より陽性菌の方が AIT 蒸気に強い抵抗性をもつと報告している。今回得られた AIT の結果も, グラム除性菌より陽性菌が強い抵抗性 を示し，ISSHIKI ら ${ }^{6)}$ の結果を確認することができた。 AIT 以外の $\omega$-Alkenyl ITC 類も AIT と同様の結果 を示した。

しかし, Aryl ITC, 類は，๘-Alkenyl 類とは反対にグラム陰性菌よりグラ 么陽性菌に高い抗菌活性を示した。これは今回初めて明 らかになったことで, ITC 類の側鎖構造によって抗菌 スペクトルが変わることを見出すことができた。

グラム陰性菌に高い抗菌活性をもつい-Alkenyl ITC 類と, グラム陽性菌の生育をよく阻止する Aryl あるい は心-MeS-NCS 類を組み合わせると, 抗菌スペクトル が拡大した。また, Alkyl ITC 以外の ITC 類は, 薬剤 而性で問題となっている MRSAに対してもMSSA と 同程度の抗菌力を示した。これらの結果は, 抗菌スペク トルの異なる ITC 類を組み合わせると, 広範用の微生 物制御が可能となることを示している。

ITC 類の抗菌力を食品保存に応用するときの要因と して, ITC 類の閾值と MIC, 香りの種類があげられる。 アリルカラシ油と AIT 蒸気の臭いの閾值は約 $3 \sim 10$ ppm と報告されている ${ }^{7), 9)}$ 。一方, MASUDA ら ${ }^{13)}$ は Alkyl ITC, $\omega$-Alkenyl ITC, Aryl ITC, $\omega$-MeSNCS 類の臭いの闇值と性状を検討し， ITC 類と Benzyl ITCの閾值は17〜75ppbときわめて 小さいのに対して，2-Phenethyl ITC の臭気閾值は
$240 \mathrm{ppb}, \omega-\mathrm{MeS}-\mathrm{NCS}$ 類は280〜800ppbで๘Alkenyl ITC 類や Benzyl ITC に比べると 1 桁高い値 であると報告している。

また, AIT を除いた心-Alkenyl ITC 類は, 沢ワサ ビの特徵的な香気 (green note) とともに，やや弱い が刺激的な匂いもあわせもつのに対して, Aryl ITC 類 は化学的あるいは強い大根様匂い，๘-MeS-NCS 類は 大根あるいはピクルス様匂いと表現され ${ }^{13)}$ ，側鎖構造の 違いによって，匂いが異なることは注目される。また， INA ら ${ }^{9)}$ は, AIT 含量の低い沢ワサビの葉と茎から, 沢 ワサビに特徵的な香気成分として -MeSO-NCS 類を検出している。

AIT とAryl ITC 類は強い抗菌力を有しているが, 臭いの閾值が小さく，しかも刺激的な匂いをあわせもつ ことから応用範囲が狭められる。一方，心-MeS-NCS 類は真菌とグラム陽性菌に対する抗菌力が強く，しかも 臭いの閾值は $\omega$-Alkenyl ITC 類や Aryl ITC 類より 1 桁高く, 刺激的な包いも小さいことから応用範囲が広い と期待できる。また，AIT 以外の心-Alkenyl 類はグラ 么陰性菌や真菌に対する抗菌力が強く, 臭いの閾值は小 さいものの green note とやや弱い刺激的な匂いをあわ せもつため, $-\mathrm{MeS}-\mathrm{NCS}$ 類と組み合わせると抗菌ス ペクトルも広がり応用面で期待される。

Alkyl ITC を除く ITC 類は, 代表的な食品保存料に 比べると 5 〜 10倍抗菌活性が高く, 抗菌スペクトルも 広かった。食品保存料のうち安息香酸 $\mathrm{Na}$, ソルビン酸 $\mathrm{K}$, プロピオン酸, デヒドロ安息香酸 $\mathrm{Na}$, 酸型保存

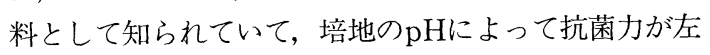
右される ${ }^{19)}$ 。酸性域 (pH 5 ) でITC 類の抗菌活性を測 定した予備実験では, 抗菌力に変動が認められなかった ことから, ITC 類は中性から酸性域で活性を示すと推 測される。今後, $\mathrm{pH}$ や食塩濃度, 温度などが ITCの 抗菌力に与える効果をさらに検討していきたい。

ITC 類は一般に非特異的な阻害剂であると考之られ ている ${ }^{20)}$ 。ITC 類の主要な抗菌作用機構として, ジス ルフィド結合の開裂による非特異的な酵素の不活性化と 微生物呼吸系の作用阻害が提案されている。

$Z_{\text {ZSOKNAI }}{ }^{21)}$ は ITC 類がジスルフィド結合を酸化的に 開裂させ，これが菌体内酵素の不活性化を引き起こし抗 菌活性を示すと述べている。KAWAKISHI とKANEKO ${ }^{22)}$ も ITC 化合物の生物活性はイソチオシアネート基に由 来し，この基が細胞質や細胞膜にあるぺプチドやたんぱ く質の官能基（たとえばスルフヒドリル基やを一アミ） 基，末端 $\alpha$ 一アミノ基など）と結合して，様々なたんぱ く質の改変を引き起こし，これが微生物の生育阻害の原 
因になっていると推測している。TANG ${ }^{11)}$ はBenzyl ITC によるパパインの活性阻害機構を，パパインの酵 素作用に係わるスルフヒドリル基を Benzyl ITCが 求 核攻撃し結合することによって失活させると述べている。

一方, AIT は終濃度 $1 \mathrm{mM}$ て酵母の酸素呼吸を $50 \%$ 以上阻害した ${ }^{23)}$ 。シトクロームcオキシダーゼ活性を 50 \%阻害するのに必要なAIT濃度は, Cyanide やアンチ マイシンAの1/100，1/5000であったことから，AITは 酸化的リン酸化の脱共役剂として機能していると推測さ れている23)。

また，ITCの重要な分解物で抗菌活性を有すること が知られているチオシアネートラジカル $\left(\mathrm{SCN}^{-}\right)$によ る代謝酵素の阻害によって抗菌活性を示すという BANKS ら ${ }^{24)}$ の報告もある。

今後, ITC 類による微生物の生育阻害機構の解明と, $\omega-\mathrm{MeS}-\mathrm{NCS}$ 類を中心に食品保存への応用に向けて具 体的な使用方法を検討していきたい。

\section{要 約}

5 種類の側鎖構造をもつ19の ITC 類の抗菌活性を検 討し, 以下の点を明らかにした。

1. Aryl ITC 類の抗菌活性が高く, 次いでの-MeSNCS 類, $\omega$-Alkenyl ITC 類, $\omega$-MeSO-NCS 類の順 で, 最も活性が低かったのは Alkyl ITC 類であった。

2. 側鎖構造の違いによって, 抗菌スペクトルが異な る傾向か認められた。Aryl ITC と心-MeS-NCS 類は 真菌とグラム陽性菌の生育をよく阻害したが，グラム陰 性菌に対する抗菌活性は低かった。一方，心-Alkenyl ITC 類は真菌とグラム陰性菌の生育をよく阻止したが, グラム陽性菌に対する抗菌活性が低かった。 NCS 類はグラム陽性菌と A. niger の生育を阻止した が，グラム陰性菌と C. albicans に対する抗菌活性は低 かった。

3. Alkyl ITC 以外の 4 種の ITC 類は, MRSA に 対しても高い抗菌活性を示し, MSSA と同濃度で生育 を阻止した。

4. 抗菌スペクトルの異なる ITC 類を組み合わせる ことにより, 抗菌スペクトルの拡大と抗菌力の増強をは かることができた。

5. Alkyl ITC を除く ITC 類は, 代表的な食品保存 料の抗菌力に比べると 5 ～10倍高い抗菌活性を示した。

MRSA を分譲いただいた財団法人広島県環境保健協 会 村上和保博士に感謝いたします。

\section{文献}

1) Nakatani, N.: In "Spices, herbs and edible fungi” (Charalambous, G. ed.) p.251 p. 271, Elsevier Science B. V., Amsterdam (1994).

2 ）一色健司 - 西宮 隆・野坂宣嘉・徳岡敬子：日食工 誌, 40, 525 (1993).

3）一色健司 - 德岡敬子：食品工業, 8, 18 (1993).

4) Inoue, S., Goi, H., Miyauchi, S., Ogihara, M., and Iwanami, Y. : J . Antibact. Antifung. Agents, 11, 609 (1983).

5 ）徳岡敬子・森理三郎・一色健司：日食工誌３9, 68 (1992)

6) Isshiki, K., ToKuokA, K., Mori, R., and ChibA, S.: Biosci. Biotechnol. Biochem., 56, 1476 (1992).

7 ）徳岡敬子.一色健司：日食工誌４1，595（1994）.

8) Delaquis, P. J., and Sholberg, P. L. : J . Food Protec.,60, 943 (1997).

9 ）伊奈和夫・高澤令子・八木昭仁・伊奈郊二・木島 勲：日食工誌，37，256（1990）.

10）伊奈和夫 - 吳 建生 $\cdot$ 衛藤英男 ·八木昭仁 · 木島 勲：日食工誌，40,859 (1993).

11) TANG, C. S.: J. Food Sci., 39,94 (1974).

12）亀岡 弘：農化，56，441（1982）.

13) Masuda, H.: Harada, Y., Tanaka, K., Nakajima, M ., and Tateba, H . : Biotechnology for Improved Foods and Flavors, 637, 67 (1996).

14）増田秀樹 - 津田 徹・立場秀樹 - 三原 智：特許 公報, 90-221255，(1990).

15）原田靖裕 - 増田秀樹 - 龟田 弥：公開特許公報, 95-215931，(1995).

16）瀬戸治男：新生化学実験講座17 微生物実験法 (東京化学同人, 東京),p. 150, (1992).

17) Carter, G. A., Garraway, J.L., Spencer, D. M., and WAIN, R. L.: Appl. Biol, ,51, 135 (1963).

18) Drobnica, L., Zemanova, M., Nemec, P., Kristian, P., Antos, and Hulka, A : Appl. Microbiol, , 15, 710 (1967).

19）野坂宣嘉・友杉 蕎: 抗菌抗力ビ技術と応用（株 式会社シーエムシ一, 東京) p.164(1996).

20) Delaquis, P. J . and Mazza, G. : Food Technology, 11, 73 (1995). 
21) Zsolnai, T.: Arnzeim, Forschung., 16, 870 (1966).

22) Kawakishi, S., and Kaneko, T. : J . Agric. Food Chem., 35, 85 (1987).

23) Kojima, M., and Ogawa, K. : J . Ferment. Technol., 49, 740 (1971).
24) BANKS, J. G., BOARD, R. G., and SPARKS, N. H. C. : Biotechnol. Appl. Biochem ., 8, 103 (1986).

平成10年 9 月 28 日受付，平成10年11月18日受理 Received Sep.28,1998; Accepted Nov.18,1998 